\title{
Changes of serum calcium levels after thyroid surgery in the elderly
}

\author{
G Patrizi, S Federici, M Fazi, F Pelle, L Fiengo, L Venturini, G Di Rocco, D Giannotti, F Frezzotti, R Giordano, \\ A Redler
}

From XXIII Annual Meeting of the Italian Society of Geriatric Surgery

Lecce, Italy. 2-4 December 2010

\section{Background}

The reasons of transient hypocalcemia in the elderly, frequent after thyroid surgery, were investigated.

\section{Materials and methods}

Serum total calcium and phosphoremia were determined in all patients who underwent thyroidectomy before and after surgery. Beside these, total protein, albumin and parathormone levels were also determined. The daily changes in serum calcemia and protein levels were measured in these patients.

\section{Results}

Transient, mild but significant decrease of serum calcium levels was observed after surgery in up to a fifth of patients, while severe hypocalcemia was shown in about $5 \%$ of patients. The reduction of calcemia was more evident in elderly patients, with a concomitant reduction of albuminemia. In severe hypocalcemia, in addition to these two findings, decrease of parathormone levels was shown.

\section{Conclusions}

We discuss the reasons for these findings, which are more frequently observed in elderly patients and the possible clinical implications to advise them to undergo total thyroidectomy.

Published: 24 August 2011

* Correspondence: g_patrizi@yahoo.com

Dipartimento di Scienze Chirurgiche, Policlinico Umberto I, Università di

Roma"La Sapienza", Rome, Italy
doi:10.1186/1471-2318-11-S1-A41

Cite this article as: Patrizi et al.: Changes of serum calcium levels after thyroid surgery in the elderly. BMC Geriatrics 2011 11(Suppl 1):A41.
Submit your next manuscript to BioMed Central and take full advantage of:

- Convenient online submission

- Thorough peer review

- No space constraints or color figure charges

- Immediate publication on acceptance

- Inclusion in PubMed, CAS, Scopus and Google Scholar

- Research which is freely available for redistribution 